TEACHING : Jurnal Inovasi Keguruan dan Ilmu Pendidikan Vol. 1. No. 4 Desember 2021 e-ISSN : 2775-7188 | p-ISSN : 2775-717X

\title{
IMPLEMENTASI MODEL PENDEKATAN BRAIN GYM UNTUK MENINGKATKAN HASIL BELAJAR MATEMATIKA
}

\author{
PARTO \\ Pascasarjana PMIPA, Universitas Indraprasta PGRI, Jakarta \\ e-mail: partojangkung@gmail.com
}

\begin{abstract}
ABSTRAK
Penelitian ini bertujuan untuk mengetahui apakah hasil belajar matematika siswa meningkat setelah dilaksanakan kegiatan belajar mengajar dengan menggunakan model pendekatan Brain Gym (senam otak). Penelitian ini menggunakan model pendekatan kualitatif dan dilakukan di SD Negeri Kebalen 05 Kecamatan Babelan Kabupaten Bekasi dengan tiga siklus. Pada siklus pertama sebagian siswa belum terbiasa dengan kondisi belajar menggunakan model pendekatan Brain Gym (senam otak) sehingga dilakukan tindakan dengan memberi penjelasan tentang prinsip-prinsip pembelajaran dengan model pendekatan Brain Gym. Di sisi lain guru sebagai kolaborator dalam penelitian ini juga belum maksimal dalam mengimplementasikan model pendekatan Brain Gym. Dalam siklus kedua siswa dan guru (kolaborator) sudah mulai memahami implementasi pembelajaran model pendekatan Brain Gym dan menunjukkan hasil yang cukup memuaskan begitu juga pada siklus ketiga. Hal ini dilihat dari hasil observasi terhadap siswa dan guru yang mengarah kepada model pendekatan Brain Gym. Dari hasil observasi, aktivitas siswa meningkat dari $52 \%$ pada siklus I, $72 \%$ pada siklus II, dan menjadi $82 \%$ pada siklus III. Sementara itu hasil ulangan harian menunjukkan peningkatan yaitu: pada siklus I dengan KKM 55,00 tuntas dengan rata-rata 63, siklus II KKM 65,00 rata-rata 71,4 dan pada siklus III KKM 65,00 rata-rata 80,6. Dari hasil pelaksanaan penelitian siklus I, II, dan III disimpulkan bahwa implementasi model pendekatan Brain Gym (senam otak) dapat meningkatkan hasil belajar dan aktivitas siswa dalam pembelajaran matematika pada kelas IV.1 SD Negeri Kebalen 05 Kecamatan Babelan Kabupaten Bekasi.
\end{abstract}

Kata Kunci: Model Pendekatan Brain Gym, Hasil Belajar, Aktivitas Siswa

\section{ABSTRACT}

This study aims to determine whether students' mathematics learning outcomes increase after teaching and learning activities are carried out using the Brain Gym approach model (brain exercise). This study used a qualitative approach model and was conducted at SD Negeri Kebalen 05, Babelan District, Bekasi Regency with three cycles. In the first cycle, some students were not familiar with learning conditions using the Brain Gym approach model (brain gymnastics) so that action was taken by explaining the principles of learning with the Brain Gym approach model. On the other hand, the teacher as a collaborator in this research has not been maximal in implementing the Brain Gym approach model. In the second cycle, students and teachers (collaborators) have begun to understand the implementation of the Brain Gym approach model learning and show quite satisfactory results as well as in the third cycle. This can be seen from the results of observations of students and teachers that lead to the Brain Gym approach model. From the results of observations, student activity increased from $52 \%$ in the first cycle, $72 \%$ in the second cycle, and to $82 \%$ in the third cycle. Meanwhile the results of daily tests showed an increase, namely: in the first cycle with KKM 55.00 completed with an average of 63, cycle II KKM 65.00 an average of 71.4 and in the third cycle KKM 65.00 an average of 80.6 . From the results of the research in cycles I, II, and III, it was concluded that the implementation of the Brain Gym approach model could improve student learning outcomes and activities in learning mathematics in class IV.1 SD Negeri Kebalen 05, Babelan District, Bekasi Regency.

Keywords: Brain Gym Approach Model, Learning Outcomes, Student Activities 


\section{PENDAHULUAN}

Matematika dipandang sebagai dasar bagi perkembangan ilmu dan teknologi, karena matematika berkenaan dengan ide-ide abstrak yang tersusun secara hierarkis dan penalarannya deduktif. Oleh karena itu matematika sebagai salah satu pelajaran pokok di sekolah-sekolah memegang peranan yang sangat penting dalam mengembangkan pola berpikir deduktif bagi siswa. Namun pada kenyataannya banyak siswa yang menganggap matematika sebagai salah satu pelajaran yang menakutkan, membosankan dan mengerikan, sehingga banyak siswa yang merasa tidak senang terhadap matematika. Dan salah satu hambatan dalam pelajaran matematika di kelas adalah banyak siswa yang tidak tertarik pada matematika. Sebagian besar penyajian matematika dalam kelas bersifat pasif sehingga siswa menjadi bosan. Hal ini serupa dengan pembelajaran tradisional yang berlangsung dibanyak sekolah dan masih menganggap siswa sebagai penerima pengetahuan yang pasif. Sehingga hasil belajar matematika di jenjangjenjang sekolah tidak dapat seperti yang diharapkan.

Di sekolah-sekolah saat ini sudah banyak pula yang beranggapan bahwa pelajaran matematika harus mengutamakan siswa belajar secara bermakna dengan menginteraksi ide yang diterima dengan pengetahuan yang dimilikinya dan membentuk tanggung jawab siswa dalam proses pembelajaran aktif. Hal yang perlu diperhatikan adalah proses belajar mengajar merupakan suatu kontak sosial antara siswa dengan guru dalam rangka mencapai tujuan pendidikan dan tujuan tersebut dapat dicapai apabila di dalam proses belajar mengajar terjadi suasana yang menyenangkan dan bermakna bagi siswa.

Dalam penciptaan kondisi kelas konduksif dibutuhkan banyak model dan variasi dalam pembelajaran matematika, agar menyenangkan, rileks, dan menarik, mulai dari penampilan guru matematika itu sendiri sampai kepada teknik, metode, model pembelajaran dan sistem di kelas. Hal ini dibutuhkan untuk mengurangi pandangan negatif tentang matematika yang sudah terlanjur terpatri dan bertujuan untuk membangkitkan dan menghidupkan motivasi belajar siswa serta menggerakkan dinamika dalam belajar matematika.Dalam pengajaran matematika, selain siswa diperkenalkan pada konsep-konsep dan teori-teori matematika, siswa juga menerapkan dalam kehidupan sehari-hari. Untuk mencapai keberhasilan dalam pelajaran matematika siswa dipengaruhi oleh beberapa faktor, diantaranya faktor internal (siswa itu sendiri) dan faktor eksternal (guru, sistem pengajaran atau metode, masyarakat atau lingkungan). Metode mempunyai pengaruh yang cukup besar dalam kegiatan belajar mengajar. Kemampuan yang diharapkan dapat dimiliki siswa, akan ditentukan oleh kesesuaian penggunaan suatu metode dengan tujuannya. Itu berarti untuk mencapai suatu tujuan pembelajaran seorang guru harus menggunakan metode yang tepat. Metode-metode tersebut diantaranya yaitu metode kooperatif, ekspositori, brain gym dan sebagainya.

Brain Gym (senam otak) adalah salah satu metode belajar yang ditemukan oleh Paul E. Dennison, Ph.D dan istrinya Gail E. Dennison sebagai bagian dari Educational-Kinesiology. Educational-Kinesiology berasal dari kata latin educare yang artinya menarik keluar dan kinesiology (kinesis) yang berasal dari kata Yunani yaitu ilmu tentang gerakan tubuh manusia. Inti dari Educational-Kinesiology yang biasa disingkat Edu-K adalah menarik keluar potensi yang terpendam melalui gerakan tubuh dan sentuhan.

Metode Brain Gym adalah bagian dari Edu-K yang menekankan gerakan tubuh untuk menyelaraskan fungsi dan penggunaan otak. Rangkaian gerakan-gerakan dalam senam otak bisa membantu dalam mengkoordinasikan tubuh dan otak. Senam otak terdiri dari beberapa gerakan sederhana yang dapat memudahkan kegiatan belajar dan mengatasi gangguangangguan belajar pada siswa. Gerakan-gerakan dalam senam otak dilakukan dalam intensitas yang cepat dan menarik sehingga dapat meningkatkan semangat siswa setelah melakukan gerakan-gerakan Brain Gym (senam otak) serta diharapkan dapat pula meningkatkan hasil belajar, motivasi, percaya diri serta tanggung jawab siswa. Sehingga dalam penelitian ini akan diteliti apakah dengan implementasi model pendekatan Brain Gym (senam otak) akan meningkatkan hasil belajar matematika siswa. 


\section{METODE PENELITIAN}

Penelitian ini merupakan penelitian tindakan kelas (classroom action research) yaitu jenis penelitian pembelajaran dalam konteks kelas yang dilakukan guru dengan tujuan untuk memecahkan problema yang dihadapi pada saat proses pembelajaran terjadi. Penelitian ini dilaksanakan di SD Negeri Kebalen 05 yang beralamat di Kp. Irian Desa Kebalen Kecamatan Babelan Kabupaten Bekasi, Jawa Barat pada kelas IV semester II Tahun Pelajaran 2009 / 2010 dengan pokok bahasan bilangan bulat. Standar Kompetensi (SK) menjumlahkan dan mengurangkan bilangan bulat. Sebagai subjek dalam penelitian ini adalah kelas IV.1 dengan jumlah siswa sebanyak 25 orang, yang terdiri dari 9 siswa laki-laki dan 16 siswa perempuan.

Pada penelitian ini dilaksanakan melalui tiga siklus yang meliputi aspek perencanaan, tindakan, observasi, dan refleksi untuk meningkatkan hasil belajar siswa dan aktifitas siswa dalam mengikuti mata pelajaran matematika melalui model pendekatan Brain Gym (senam otak). Metode pengumpulan data pada penelitian ini adalah observasi, wawancara, angket, dan tes. Observasi dilakukan untuk mengamati aktivitas siswa selama kegiatan pembelajaran berlangsung, dari observasi tersebut dapat dilihat peningkatan aktivitas belajar siswa yang meliputi frekuensi aktivitas, peningkatan konsentrasi, peningkatan disiplin belajar, peningkatan perhatian siswa, dan peningkatan tanggung jawab siswa dalam pembelajaran matematika. Wawancara pada penelitian ini menggunakan wawancara tidak berstruktur karena peneliti memandang model ini adalah yang paling luwes, dimana subjek diberi kebebasan untuk menguraikan jawabannya dan ungkapan-ungkapan pandangan secara bebas dan sesuai hatinya. Angket pada penelitian ini menggunakan pernyataan yang terikat (terstruktur). Angket ini digunakan untuk mengetahui pendapat atau sikap siswa terhadap pembelajaran Brain Gym (senam otak) pada proses belajar mengajar pada pelajaran matematika. Sedangkan untuk tes dilakukan untuk mengetahui kemampuan awal siswa sehingga peneliti dapat merencanakan tindakan yang akan diambil dalam memperbaiki proses pembelajaran selanjutnya. Pemberian tindakan dilakukan dalam tiga siklus dan evaluasi dilakukan diakhir siklus untuk mengetahui hasil belajar matematika siswa pada setiap siklus.

Metode analisis data yang digunakan adalah reduksi data, penyajian data, dan penarikan kesimpulan. Data yang diperoleh dicari hubungannya atau hal-hal yang sering timbul dari data tersebut dengan temuan penelitian atau hasil penelitian. Pengambilan kesimpulan dilakukan terhadap temuan penelitian berupa indikator-indikator yang selanjutnya dilakukan pemaknaan atau refleksi sehingga memperoleh kesimpulan akhir. Hasil kesimpulan akhir dilakukan refleksi untuk menentukan atau menyusun rencana tindakan berikutnya.

\section{HASIL DAN PEMBAHASAN}

Pelaksanaan penelitian dilakukan secara kolaborasi dengan teman sejawat, yang membantu dalam pelaksanaan observasi dan refleksi selama penelitian berlangsung, sehingga secara tidak langsung kegiatan penelitian bisa terkontrol sekaligus menjaga keabsahan hasil dari penelitian.

Hasil

1. Angket

Sebelum memaparkan hasil penelitian, terlebih dahulu akan disajikan data hasil angket sebagai refleksi awal, angket setelah KBM siklus I, II, dan III yang terdapat pada tabel 1 sampai dengan tabel 4.4 dibawah ini.

Tabel 1. Hasil Angket Siswa Sebagai Refleksi Awal

\begin{tabular}{llcc}
\hline No. & \multicolumn{1}{c}{ Pernyataan } & \multicolumn{2}{c}{ Jawaban } \\
\cline { 3 - 4 } & \multicolumn{1}{c}{ Setuju } & $\begin{array}{c}\text { Tidak } \\
\text { Setuju }\end{array}$ \\
\hline $\begin{array}{l}\text { 1. } \\
\text { 2. } \begin{array}{l}\text { Gatematika merupakan mata pelajaran yang sulit. } \\
\text { otak). }\end{array}\end{array}$ & $68 \%$ & $32 \%$ \\
& $100 \%$ & $0 \%$
\end{tabular}


3. Siswa senang dengan metode pembelajaran yang diterapkan oleh guru selama ini.

$44 \% \quad 56 \%$

4. Siswa merasa termotivasi untuk belajar saat guru mengajar dikelas. $\quad 32 \% \quad 68 \%$

5. Siswa menginginkan adanya model pembelajaran yang baru. $\quad 80 \% \quad 20 \%$

6. Siswa puas dengan hasil ulangan yang diperoleh selama ini. $\quad 24 \% \quad 76 \%$

Tabel 2. Hasil Angket Siswa Siklus I Setelah Kegiatan Belajar Mengajar

\begin{tabular}{lllc}
\hline & \multicolumn{1}{c}{ Pernyataan } & \multicolumn{2}{c}{ Jawaban } \\
\cline { 2 - 4 } No. & Setuju & $\begin{array}{c}\text { Tidak } \\
\text { Setuju }\end{array}$ \\
\hline 1. & $\begin{array}{l}\text { Pembelajaran matematika dengan model pendekatan Brain Gym } \\
\text { (senam otak) menyenangkan. }\end{array}$ & $72 \%$ & $28 \%$ \\
2. & $\begin{array}{l}\text { Dengan melakukan gerakan-gerakan Brain Gym (senam otak) } \\
\text { membuat saya mudah memahami pelajaran. }\end{array}$ & $60 \%$ & $40 \%$ \\
3. & $\begin{array}{l}\text { Pembelajaran model pendekatan Brain Gym (senam otak) } \\
\text { membuat saya berani dan percaya diri dalam mengemukakan }\end{array}$ & $68 \%$ & $32 \%$ \\
4. & $\begin{array}{l}\text { Pemapat. } \\
\text { membelajaran model pendekatan Brain Gym (senam otak) }\end{array}$ & $68 \%$ & $32 \%$ \\
5. Saya mengalami kesulitan dalam pembelajaran Brain Gym (senam \\
otak).
\end{tabular}

Tabel 3. Hasil Angket Siswa Siklus II Setelah Kegiatan Belajar Mengajar

\begin{tabular}{|c|c|c|c|}
\hline \multirow[b]{2}{*}{ No. } & \multirow[b]{2}{*}{ Pernyataan } & \multicolumn{2}{|c|}{ Jawaban } \\
\hline & & Setuju & $\begin{array}{l}\text { Tidak } \\
\text { Setuju }\end{array}$ \\
\hline 1. & $\begin{array}{l}\text { Pembelajaran matematika dengan model pendekatan Brain Gym } \\
\text { (senam otak) menyenangkan. }\end{array}$ & $84 \%$ & $16 \%$ \\
\hline 2. & $\begin{array}{l}\text { Dengan melakukan gerakan-gerakan Brain Gym (senam otak) } \\
\text { membuat saya mudah memahami pelajaran. }\end{array}$ & $80 \%$ & $20 \%$ \\
\hline 3. & $\begin{array}{l}\text { Pembelajaran model pendekatan Brain Gym (senam otak) } \\
\text { membuat saya berani dan percaya diri dalam mengemukakan } \\
\text { pendapat. }\end{array}$ & $80 \%$ & $20 \%$ \\
\hline 4. & $\begin{array}{l}\text { Pembelajaran model pendekatan Brain Gym (senam otak) } \\
\text { memotivasi saya untuk lebih aktif. }\end{array}$ & $88 \%$ & $12 \%$ \\
\hline 5. & $\begin{array}{l}\text { Saya mengalami kesulitan dalam pembelajaran Brain Gym (senam } \\
\text { otak). }\end{array}$ & $24 \%$ & $76 \%$ \\
\hline
\end{tabular}

Tabel 4. Hasil Angket Siswa Siklus III Setelah Kegiatan Belajar Mengajar

No.

Pernyataan

Jawaban

\begin{tabular}{llcc} 
No. & \multicolumn{1}{c}{ Pernyataan } & Setuju & $\begin{array}{c}\text { Tidak } \\
\text { Setuju }\end{array}$ \\
\hline 1. & $\begin{array}{l}\text { Pembelajaran matematika dengan model pendekatan Brain Gym } \\
\text { (senam otak) menyenangkan. }\end{array}$ & $92 \%$ & $8 \%$ \\
2. & $\begin{array}{l}\text { Dengan melakukan gerakan-gerakan Brain Gym (senam otak) } \\
\text { membuat saya mudah memahami pelajaran. }\end{array}$ & $88 \%$ & $12 \%$ \\
3. & $\begin{array}{l}\text { Pembelajaran model pendekatan Brain Gym (senam otak) } \\
\text { membuat saya berani dan percaya diri dalam mengemukakan } \\
\text { pendapat. }\end{array}$ & $96 \%$ & $4 \%$ \\
4. Pembelajaran model pendekatan Brain Gym (senam otak) \\
memotivasi saya untuk lebih aktif.
\end{tabular}


5. Saya mengalami kesulitan dalam pembelajaran Brain Gym (senam otak).

$4 \% \quad 96 \%$

2. Wawancara

Wawancara digunakan untuk mendapatkan data tentang pendapat siswa mengenai implementasi model pendekatan Brain Gym (senam otak) pada materi bilangan bulat. Hasil wawancara atau interview kepada responden siswa dan teman sejawat pada penelitian tindakan kelas siklus I, II, dan III dapat dilihat pada tabel 5 sampai dengan tabel 8 dibawah ini serta panduan wawancara yang dipergunakan.

Tabel 5. Hasil Wawancara Siklus I Responden Siswa

\begin{tabular}{|c|c|c|c|c|c|c|}
\hline \multirow{2}{*}{ Siklus } & \multirow{2}{*}{$\begin{array}{c}\text { Nama } \\
\text { Responden }\end{array}$} & \multicolumn{5}{|c|}{ Jawaban } \\
\hline & & 1 & 2 & $\mathbf{3}$ & 4 & 5 \\
\hline \multirow{5}{*}{$\begin{array}{l}\text { Siklus } \\
\text { I }\end{array}$} & Siska & $\begin{array}{l}\text { Bagus, gerakannya } \\
\text { menyehatkan }\end{array}$ & $\mathrm{Ya}$ & $\begin{array}{l}\text { Sulit, belum pernah } \\
\text { diajarkan. }\end{array}$ & $\begin{array}{l}\text { Ya, materinya } \\
\text { tidak sulit. }\end{array}$ & $\begin{array}{l}\text { Gerakannya } \\
\text { dibuat lebih } \\
\text { mudah. }\end{array}$ \\
\hline & Ceacar & $\begin{array}{l}\text { Biasa, tidak dapat } \\
\text { melakukan gerakan } \\
\text { dengan baik. }\end{array}$ & $\mathrm{Ya}$ & Sulit, belum belajar. & $\begin{array}{l}\text { Tidak paham, } \\
\text { tidak } \\
\text { konsentrasi. }\end{array}$ & $\begin{array}{l}\text { Langkah gerakan } \\
\text { diperlambat. }\end{array}$ \\
\hline & Nanda MJ & $\begin{array}{l}\text { Baik, membuat } \\
\text { semangat belajar. }\end{array}$ & Tidak & $\begin{array}{l}\text { Mudah, sudah } \\
\text { belajar. }\end{array}$ & $\begin{array}{l}\text { Ya, dapat } \\
\text { fokus belajar }\end{array}$ & $\begin{array}{l}\text { Penyampaian } \\
\text { materi lebih } \\
\text { jelas. }\end{array}$ \\
\hline & Ika MW & $\begin{array}{l}\text { Bagus, gerakannya } \\
\text { menyenangkan. }\end{array}$ & Tidak & $\begin{array}{l}\text { Sulit, belum pernah } \\
\text { diajarkan. }\end{array}$ & $\begin{array}{l}\text { Ya, materinya } \\
\text { tidak sulit. }\end{array}$ & $\begin{array}{l}\text { Gerakan lebih } \\
\text { detail. }\end{array}$ \\
\hline & A.Muchtar & $\begin{array}{l}\text { Biasa, sulit } \\
\text { gerakannya }\end{array}$ & $\mathrm{Ya}$ & $\begin{array}{l}\text { Sulit, tidak dapat } \\
\text { mengerjakannya. }\end{array}$ & $\begin{array}{l}\text { Tidak, tentang } \\
\text { bilangan bulat. }\end{array}$ & $\begin{array}{l}\text { Soal latihan } \\
\text { dibuat mudah. }\end{array}$ \\
\hline
\end{tabular}

Tabel 6. Hasil Wawancara Siklus II Responden Siswa

\begin{tabular}{|c|c|c|c|c|c|c|}
\hline \multirow{2}{*}{ Siklus } & \multirow{2}{*}{$\begin{array}{c}\text { Nama } \\
\text { Responden }\end{array}$} & \multicolumn{5}{|c|}{ Jawaban } \\
\hline & & 1 & 2 & 3 & 4 & 5 \\
\hline \multirow{5}{*}{$\begin{array}{l}\text { Siklus } \\
\text { II }\end{array}$} & Dhimas & $\begin{array}{l}\text { Menyenangkan, } \\
\text { gerakannya mudah. }\end{array}$ & Tidak & Mudah, lebih fokus. & $\begin{array}{l}\text { Ya, pemberian } \\
\text { materi jelas. }\end{array}$ & Guru lebih aktif. \\
\hline & Rizky & $\begin{array}{l}\text { Cukup baik, ada } \\
\text { gerakan yang tidak } \\
\text { bisa. }\end{array}$ & $\mathrm{Ya}$ & $\begin{array}{l}\text { Tidak sulit, ada soal } \\
\text { yang tidak mengerti. }\end{array}$ & $\begin{array}{l}\text { Belum, tidak } \\
\text { konsentrasi. }\end{array}$ & $\begin{array}{l}\text { Langkah gerakan } \\
\text { lebih jelas. }\end{array}$ \\
\hline & Tata & $\begin{array}{l}\text { Bagus, memotivasi } \\
\text { untuk belajar. }\end{array}$ & Tidak & $\begin{array}{l}\text { Mudah, senam otak } \\
\text { membantu } \\
\text { konsentrasi. }\end{array}$ & $\begin{array}{l}\text { Ya, materinya } \\
\text { mudah. }\end{array}$ & $\begin{array}{l}\text { Ditambah } \\
\text { variatif } \\
\text { gerakannya. }\end{array}$ \\
\hline & Putri & $\begin{array}{l}\text { Baik, lebih semangat } \\
\text { belajar. }\end{array}$ & $\mathrm{Ya}$ & $\begin{array}{l}\text { Sulit, tidak semua } \\
\text { dikerjakan. }\end{array}$ & $\begin{array}{l}\text { Ya, pemberian } \\
\text { materi jelas. }\end{array}$ & $\begin{array}{l}\text { Latihan soal } \\
\text { lebih mudah. }\end{array}$ \\
\hline & Metia & $\begin{array}{l}\text { Menyenangkan, } \\
\text { dapat melakukan } \\
\text { dengan baik. }\end{array}$ & Tidak & $\begin{array}{l}\text { Cukup mudah, } \\
\text { sudah belajar. }\end{array}$ & $\begin{array}{l}\text { Ya, pemberian } \\
\text { materi jelas. }\end{array}$ & $\begin{array}{l}\text { Langkah } \\
\text { gerakan lebih } \\
\text { detail }\end{array}$ \\
\hline
\end{tabular}

Tabel 7. Hasil Wawancara Siklus III Responden Siswa

\begin{tabular}{|c|c|c|c|c|c|c|}
\hline \multirow{2}{*}{ Siklus } & \multirow{2}{*}{$\begin{array}{c}\text { Nama } \\
\text { Responden }\end{array}$} & \multicolumn{5}{|c|}{ Jawaban } \\
\hline & & 1 & 2 & 3 & 4 & 5 \\
\hline & Alam & $\begin{array}{l}\text { Bagus, lebih percaya } \\
\text { diri. }\end{array}$ & Tidak & $\begin{array}{l}\text { Mudah, dapat } \\
\text { mengerjakan } \\
\text { dengan baik }\end{array}$ & $\begin{array}{l}\text { Ya, lebih } \\
\text { konsentrasi. }\end{array}$ & $\begin{array}{l}\text { Ditambah } \\
\text { gerakannya. }\end{array}$ \\
\hline $\begin{array}{l}\text { Siklus } \\
\text { III }\end{array}$ & Arlian & $\begin{array}{l}\text { Menyenangkan, } \\
\text { gerakannya mudah } \\
\text { dilakukan }\end{array}$ & Tidak & $\begin{array}{l}\text { Mudah, dapat } \\
\text { menjawab semua } \\
\text { soal. }\end{array}$ & $\begin{array}{l}\text { Ya, pemberian } \\
\text { materi jelas. }\end{array}$ & $\begin{array}{l}\text { Soal dibuat } \\
\text { lebih variatif. }\end{array}$ \\
\hline & Dwi & $\begin{array}{l}\text { Baik, menjadi lebih } \\
\text { aktif. }\end{array}$ & Tidak & $\begin{array}{l}\text { Mudah, dapat } \\
\text { mengerjakannya. }\end{array}$ & $\begin{array}{l}\text { Ya, lebih } \\
\text { konsentrasi. }\end{array}$ & $\begin{array}{l}\text { Guru lebih aktif } \\
\text { membimbing } \\
\text { siswa. }\end{array}$ \\
\hline
\end{tabular}


TEACHING : Jurnal Inovasi Keguruan dan IImu Pendidikan

Vol. 1. No. 4 Desember 2021 e-ISSN : 2775-7188 | p-ISSN : 2775-717X

\begin{tabular}{clllll}
\hline Novita & $\begin{array}{l}\text { Biasa, tidak } \\
\text { sempurna } \\
\text { gerakannya. }\end{array}$ & Ya & $\begin{array}{l}\text { Cukup mudah, } \\
\text { materi jelas. }\end{array}$ & $\begin{array}{l}\text { Ya, pernah } \\
\text { mempelajari. }\end{array}$ & $\begin{array}{l}\text { Gerakannya } \\
\text { dibuat lebih } \\
\text { mudah. }\end{array}$ \\
Sella & Tikup baik, & Tidak & Tidak sulit, dapat \\
menyenangkan. & & mengerjakannya. & $\begin{array}{l}\text { Ya, } \\
\text { pemberian } \\
\text { materi jelas. }\end{array}$ & $\begin{array}{l}\text { Waktu } \\
\text { melakukan } \\
\text { gerakan } \\
\text { ditambah }\end{array}$ \\
\hline
\end{tabular}

Tabel 8. Hasil Wawancara Siklus I, II, dan III Responden Teman Sejawat

\begin{tabular}{|c|c|c|c|c|c|c|}
\hline \multirow{2}{*}{ Siklus } & \multirow{2}{*}{$\begin{array}{c}\text { Nama } \\
\text { Responden }\end{array}$} & \multicolumn{5}{|c|}{ Jawaban } \\
\hline & & 1 & 2 & 3 & 4 & 5 \\
\hline $\begin{array}{l}\text { Siklus } \\
\text { I }\end{array}$ & $\begin{array}{c}\text { Siti } \\
\text { Khodijah }\end{array}$ & $\begin{array}{l}\text { Cukup baik, } \\
\text { masih banyak } \\
\text { yang perlu } \\
\text { diperbaiki. }\end{array}$ & $\begin{array}{l}\text { Keaktifan siswa } \\
\text { yang mulai } \\
\text { berkembang. }\end{array}$ & $\begin{array}{l}\text { Penjelasan } \\
\text { langkah-langkah } \\
\text { gerakan Brain } \\
\text { Gym lebih } \\
\text { detail. }\end{array}$ & $\begin{array}{l}\text { Belum yakin, } \\
\text { karena gerakan } \\
\text { yang dilakukan } \\
\text { belum benar. }\end{array}$ & $\begin{array}{l}\text { Guru lebih } \\
\text { aktif dalam } \\
\text { membimbing } \\
\text { siswa. }\end{array}$ \\
\hline $\begin{array}{l}\text { Siklus } \\
\text { II }\end{array}$ & $\begin{array}{c}\text { Siti } \\
\text { Khodijah }\end{array}$ & $\begin{array}{l}\text { Baik, karena } \\
\text { Brain Gym } \\
\text { memotivasi siswa } \\
\text { untuk belajar. }\end{array}$ & $\begin{array}{l}\text { Penjelasan } \\
\text { materi yang } \\
\text { cukup baik. }\end{array}$ & $\begin{array}{l}\text { Bimbingan } \\
\text { menyeluruh } \\
\text { kepada semua } \\
\text { siswa. }\end{array}$ & $\begin{array}{l}\text { Ya, karena } \\
\text { gerakannya } \\
\text { membantu fokus } \\
\text { dan konsentrasi } \\
\text { siswa. }\end{array}$ & $\begin{array}{l}\text { Penjelasan } \\
\text { gerakan senam } \\
\text { otak lebih } \\
\text { detail lagi. }\end{array}$ \\
\hline $\begin{array}{l}\text { Siklus } \\
\text { III }\end{array}$ & $\begin{array}{c}\text { Siti } \\
\text { Khodijah }\end{array}$ & $\begin{array}{l}\text { Lebih baik, karena } \\
\text { KBM mengarah } \\
\text { ke proses } \\
\text { pembelajaran } \\
\text { Brain Gym. }\end{array}$ & $\begin{array}{l}\text { Pemberian } \\
\text { materi yang } \\
\text { cukup jelas. }\end{array}$ & $\begin{array}{l}\text { Variatif gerakan } \\
\text { yang perlu } \\
\text { ditambah. }\end{array}$ & $\begin{array}{l}\text { Ya, karena Brain } \\
\text { Gym } \\
\text { memotivasi } \\
\text { siswa untuk } \\
\text { belajar. }\end{array}$ & $\begin{array}{l}\text { Guru } \\
\text { menambah } \\
\text { variatif } \\
\text { gerakan senam } \\
\text { otak. }\end{array}$ \\
\hline
\end{tabular}

\section{Tes}

Tes dilakukan untuk mengetahui kemampuan awal siswa sehingga peneliti dapat merencanakan tindakan yang akan diambil dalam memperbaiki proses pembelajaran selanjutnya. Pemberian tindakan dilakukan dalam tiga siklus dan evaluasi dilakukan diakhir siklus untuk mengetahui hasil belajar matematika siswa pada setiap siklus. Hasil tes yang didapat siswa pada siklus I, II, dan III dapat dilihat pada tabel 4.10 sampai dengan tabel 4.13 dibawah ini:

Tabel 9. Hasil Tes Siklus I Latihan Soal ( Pre-Activity \& Post-Activity )

\begin{tabular}{clccc}
\hline No & \multicolumn{1}{c}{ Nama Siswa } & Pre-Activity & Post-Activity & Poin Peningkatan \\
\hline 1. & A.Muchtar & 50 & 60 & 10 \\
2. & Alam Avif Makarim & 80 & 80 & 0 \\
3. & Anselmus Renanta.G & 70 & 80 & 10 \\
4. & Arlian Collibri & 40 & 60 & 20 \\
5. & Ayulina Kurniawati & 70 & 80 & 10 \\
6. & Bimby Julidah & 40 & 60 & 20 \\
7. & Ceacar Andrian R & 50 & 60 & 10 \\
8. & Dhimas Rizky D & 80 & 90 & 10 \\
9. & Dwi Kartika Putri & 30 & 60 & 30 \\
10. & Fauziah Haliyane & 70 & 80 & 10 \\
11. & Ika Mustika Wati & 40 & 60 & 20 \\
12. & M.Hidayatul Asthoni & 90 & 100 & 10 \\
13. & Metia Sonia & 70 & 80 & 10 \\
14. & Nanda Mas Januran & 80 & 90 & 10 \\
15. & Novita Indriyani & 40 & 60 & 20 \\
16. & Nurkamila Rahma A & 40 & 70 & 30 \\
17. & Putri Nurmaini & 30 & 60 & 30 \\
18. & Rafi Nurfaizi & 70 & 80 & 10 \\
19. & Resita Rus Alviolyn & 70 & 70 & 0 \\
20. & Risna Wulan Dewi & 40 & 60 & 20 \\
21. & Rizky Ananda Astari & 40 & 60 & 20 \\
22. & Rizky Syahputra & 50 & 60 & 10 \\
23. & Sella Faria Ginta & 70 & 80 & 10 \\
\hline
\end{tabular}


TEACHING : Jurnal Inovasi Keguruan dan IImu Pendidikan

Vol. 1. No. 4 Desember 2021 e-ISSN : 2775-7188 | p-ISSN : 2775-717X

\begin{tabular}{ccccc}
\hline 24. & Siska & 50 & 70 & 20 \\
25. & Tata Aditya Putri & 90 & 100 & 10 \\
\hline & Jumlah & 1450 & 1810 & 360 \\
\hline & Rata-rata & 58 & 72.4 & 14.4 \\
\hline
\end{tabular}

Tabel 10. Hasil Tes Siklus II Latihan Soal ( Pre-Activity \& Post-Activity )

\begin{tabular}{clccc}
\hline No & \multicolumn{1}{c}{ Nama Siswa } & Pre-Activity & Post-Activity & Poin Peningkatan \\
\hline 1. & A.Muchtar & 70 & 80 & 10 \\
2. & Alam Avif Makarim & 60 & 70 & 10 \\
3. & Anselmus Renanta.G & 70 & 80 & 10 \\
4. & Arlian Collibri & 40 & 60 & 20 \\
5. & Ayulina Kurniawati & 80 & 90 & 10 \\
6. & Bimby Julidah & 60 & 90 & 30 \\
7. & Ceacar Andrian R & 50 & 70 & 20 \\
8. & Dhimas Rizky D & 70 & 80 & 10 \\
9. & Dwi Kartika Putri & 40 & 60 & 20 \\
10. & Fauziah Haliyane & 70 & 80 & 10 \\
11. & Ika Mustika Wati & 70 & 80 & 10 \\
12. & M.Hidayatul Asthoni & 90 & 100 & 10 \\
13. & Metia Sonia & 50 & 70 & 20 \\
14. & Nanda Mas Januran & 70 & 90 & 20 \\
15. & Novita Indriyani & 40 & 60 & 20 \\
16. & Nurkamila Rahma A & 60 & 80 & 20 \\
17. & Putri Nurmaini & 50 & 70 & 20 \\
18. & Rafi Nurfaizi & 60 & 80 & 20 \\
19. & Resita Rus Alviolyn & 70 & 80 & 10 \\
20. & Risna Wulan Dewi & 70 & 80 & 10 \\
21. & Rizky Ananda Astari & 50 & 70 & 20 \\
22. & Rizky Syahputra & 60 & 70 & 10 \\
23. & Sella Faria Ginta & 80 & 90 & 10 \\
24. & Siska & 60 & 80 & 20 \\
25. & Tata Aditya Putri & 70 & 100 & 30 \\
\hline & $\quad$ Jumlah & 1560 & 1960 & 16 \\
\hline & Rata-rata & & & \\
\hline
\end{tabular}

Tabel 11. Hasil Tes Siklus III Latihan Soal ( Pre-Activity \& Post-Activity )

\begin{tabular}{clccc}
\hline No & \multicolumn{1}{c}{ Nama Siswa } & Pre-Activity & Post-Activity & Poin Peningkatan \\
\hline 1. & A.Muchtar & 70 & 90 & 20 \\
2. & Alam Avif Makarim & 70 & 80 & 10 \\
3. & Anselmus Renanta.G & 60 & 80 & 20 \\
4. & Arlian Collibri & 70 & 90 & 20 \\
5. & Ayulina Kurniawati & 80 & 90 & 10 \\
6. & Bimby Julidah & 60 & 80 & 20 \\
7. & Ceacar Andrian R & 50 & 60 & 10 \\
8. & Dhimas Rizky D & 60 & 80 & 20 \\
9. & Dwi Kartika Putri & 70 & 80 & 10 \\
10. & Fauziah Haliyane & 80 & 90 & 10 \\
11. & Ika Mustika Wati & 40 & 70 & 30 \\
12. M.Hidayatul Asthoni & 80 & 100 & 20 \\
13. Metia Sonia & 50 & 70 & 20 \\
14. & Nanda Mas Januran & 80 & 100 & 20 \\
15. & Novita Indriyani & 60 & 90 & 30 \\
16. & Nurkamila Rahma A & 60 & 80 & 20 \\
17. & Putri Nurmaini & 80 & 100 & 20 \\
18. & Rafi Nurfaizi & 70 & 90 & 20 \\
19. & Resita Rus Alviolyn & 70 & 80 & 10 \\
21. & Rizky Ananda Astari & 60 & 80 & 20 \\
22. & Rizky Syahputra & 60 & 70 & 10 \\
23. & Sella Faria Ginta & 60 & 80 & 20 \\
24. & Siska & 50 & 90 & 40 \\
25. & Tata Aditya Putri & 60 & 80 & 20 \\
\hline
\end{tabular}


TEACHING : Jurnal Inovasi Keguruan dan IImu Pendidikan Vol. 1. No. 4 Desember 2021 e-ISSN : 2775-7188 | p-ISSN : 2775-717X

\begin{tabular}{cccc}
\hline Jumlah & 1620 & 2090 & 470 \\
\hline Rata-rata & 64.8 & 83.6 & 18.8 \\
\hline
\end{tabular}

Tabel 12. Hasil Tes Ulangan Harian Siklus I, II, dan III

\begin{tabular}{|c|c|c|c|c|}
\hline No & Nama Siswa & Siklus I & Siklus II & Siklus III \\
\hline 1. & A.Muchtar & 70 & 75 & 80 \\
\hline 2. & Alam Avif Makarim & 70 & 70 & 75 \\
\hline 3. & Anselmus Renanta.G & 50 & 60 & 75 \\
\hline 4. & Arlian Collibri & 45 & 65 & 100 \\
\hline 5. & Ayulina Kurniawati & 90 & 90 & 75 \\
\hline 6. & Bimby Julidah & 70 & 75 & 80 \\
\hline 7. & Ceacar Andrian Renwari & 65 & 70 & 75 \\
\hline 8. & Dhimas Rizky Dwitanto & 70 & 75 & 80 \\
\hline 9. & Dwi Kartika Putri & 70 & 80 & 90 \\
\hline 10. & Fauziah Haliyane & 60 & 70 & 80 \\
\hline 11. & Ika Mustika Wati & 40 & 60 & 75 \\
\hline 12. & M.Hidayatul Asthoni & 80 & 90 & 90 \\
\hline 13. & Metia Sonia & 40 & 60 & 75 \\
\hline 14. & Nanda Mas Januran & 60 & 65 & 75 \\
\hline 15 . & Novita Indriyani & 70 & 75 & 80 \\
\hline 16. & Nurkamila Rahma Andini & 45 & 65 & 75 \\
\hline 17. & Putri Nurmaini & 60 & 70 & 80 \\
\hline 18. & Rafi Nurfaizi & 40 & 60 & 75 \\
\hline 19. & Resita Rus Alviolyn & 70 & 80 & 90 \\
\hline 20. & Risna Wulan Dewi & 55 & 65 & 75 \\
\hline 21. & Rizky Ananda Astari & 65 & 70 & 75 \\
\hline 22. & Rizky Syahputra & 65 & 70 & 80 \\
\hline 23. & Sella Faria Ginta & 70 & 70 & 75 \\
\hline 24. & Siska & 85 & 80 & 100 \\
\hline 25. & Tata Aditya Putri & 70 & 75 & 85 \\
\hline & Jumlah & 1575 & 1785 & 2015 \\
\hline & Rata-rata & 63 & 71.4 & 80.6 \\
\hline
\end{tabular}

\section{Pembahasan}

Dari tabel menunjukkan bahwa sebagian besar siswa kelas IV.1 SD Negeri Kebalen 05 menyatakan matematika merupakan pelajaran yang sulit $(68 \%)$ dan siswa yang merasa tidak puas dengan hasil ulangan yang diperoleh selama ini sekitar $76 \%$. Siswa merasa jenuh dengan metode mengajar yang selama ini diterapkan oleh guru. $80 \%$ siswa menginginkan adanya variasi model pembelajaran yang baru dan $68 \%$ siswa merasa kurang termotivasi dengan metode pembelajaran yang diterapkan selama ini. Hasil penelitian menunjukkan bahwa pembelajaran dengan model pendekatan Brain Gym (senam otak) pada setiap siklus mengalami peningkatan, walaupun belum sepenuhnya berjalan dengan baik pada setiap siklus.

Perkembangan pada siklus I dapat dilihat dari guru yang belum mampu dalam mengelola pembelajaran dan banyak siswa yang belum terbiasa dengan model pembelajaran Brain Gym (senam otak). Siswa belum mampu mengerjakan tugas/ soal yang diberikan oleh guru dengan baik, hal ini terjadi karena kurangnya motivasi untuk belajar dan bimbingan guru sehingga sebagian besar siswa masih bersikap pasif. Hanya beberapa siswa yang aktif dalam pembelajaran dan melakukan menu gerakan-gerakan Brain Gym (senam otak) dengan baik. Alokasi waktu yang tersedia pada rencana pembelajaran tidak tercapai dengan tepat, dimana guru belum dapat melakukan efisiensi waktu ketika learning menu dan pemberian materi pelajaran, sehingga waktu yang tersedia tidak mencukupi.

Pada siklus II guru telah mampu mengelola pembelajaran dengan model pendekatan Brain Gym (senam otak) dengan cukup baik dan siswa terlihat mulai terbiasa dengan pembelajaran yang baru. Guru telah mampu memotivasi siswa untuk belajar dan bimbingan guru hampir merata pada semua siswa dalam melakukan gerakan-gerakan Brain Gym (senam otak) yang terdapat dalam learning menu. Hanya sebagian kecil saja siswa yang masih pasif 


\section{TEACHING : Jurnal Inovasi Keguruan dan IImu Pendidikan Vol. 1. No. 4 Desember 2021 e-ISSN : 2775-7188 | p-ISSN : 2775-717X}

untuk tidak/ belum sempurna melakukan beberapa gerakan Brain Gym (senam otak) dengan baik. Pengaturan dan efisiensi waktu sudah lebih baik dari siklus sebelumnya serta sesuai rencana pelaksanaan pembelajaran. Pada siklus II ini guru telah mampu mengatasi masalah yang menghambat proses belajar mengajar dengan mengadakan perbaikan-perbaikan pada beberapa aspek yang masih memilki kekurangan. Sehingga kegiatan belajar mengajar yang menggunakan model pendekatan Brain Gym (senam otak) dapat berjalan dengan baik.

Pada siklus III guru telah mengelola pembelajaran dengan model pendekatan Brain Gym (senam otak) dengan baik dan siswa lebih antusias, fokus, dan berkonsentrasi secara penuh untuk mengikuti proses belajar mengajar dikelas. Guru lebih intensif membimbing siswa yang mengalami kesulitan dalam melakukan gerakan-gerakan Brain Gym (senam otak) yang ada pada learning menu, serta bimbingan guru telah merata kepada semua siswa dikelas. Pengaturan dan efisiensi waktu sudah lebih baik, sehingga kegiatan belajar mengajar sesuai dengan rencana pelaksanaan pembelajaran. Pada siklus III ini guru mampu mengatasi masalah yang menghambat proses pembelajaran pada siklus sebelumnya dengan mengadakan perbaikan-perbaikan di beberapa aspek agar lebih baik pada proses pembelajaran selanjutnya.

Secara keseluruhan kegiatan pembelajaran dengan model pendekatan Brain Gym (senam otak) pada siklus III berlangsung lebih baik dari pada siklus-siklus yang sebelumnya, sehingga dapat dikatakan bahwa pengelolaan kegiatan pembelajaran Brain Gym (senam otak) telah berlangsung secara efektif.

Pembelajaran model pendekatan Brain Gym (senam otak) yang dilaksanakan guru telah mampu menumbuhkan dan meningkatkan motivasi belajar siswa sehingga hasil belajar matematika siswa kelas IV.1 SD Negeri Kebalen 05 Kecamatan Babelan Kabupaten Bekasi meningkat. Terutama adanya penghargaan kepada siswa yang mendapatkan nilai terbaik serta dapat melakukan gerakan-gerakan Brain Gym (senam otak) dengan baik. Pemberian penghargaan ini dapat memunculkan efek positif pada siswa, sehingga siswa semakin antusias untuk belajar. Salah satu cara untuk memunculkan motivasi siswa adalah dengan mengangkat semua hal positif, dengan mengetahui kelebihan-kelebihan siswa dan menggunakan kelebihan itu sebagai bahan dasar untuk membangun motivasi siswa. Menyingkirkan hal negatif dengan cara tidak merendahkan kelemahan siswa tapi menjadikan kelemahan itu sebagai motivasi siswa untuk lebih baik lagi. Hal ini sejalan dengan penelitian Wuri Hartanti (2010) "Penerapan brain gym untuk meningkatkan kemampuan menulis permulaan anak di kelompok A Taman Kanak-kanak", Kartinah (2010) "Eksperimentasi model pembelajaran yang diawali dengan senam otak (brain gym) terhadap prestasi belajar matematika ditinjau dari kemampuan awal siswa sma se kabupaten Kotawaringin Timur Sampit tahun pelajaran 2009/2010" yang menyatakan bahwa brain gym mampu meningkatkan hasil belajar siswa.

\section{KESIMPULAN}

Kesimpulan yang dapat diambil dari hasil penelitian tindakan kelas (classroom action research) ini adalah sebagai berikut:

1. Implementasi model pendekatan Brain Gym (senam otak) dapat meningkatkan hasil belajar matematika siswa dan aktivitas siswa dalam proses belajar mengajar.

2. Hasil observasi memperlihatkan bahwa terjadi peningkatan aktivitas siswa yang pada siklus I hanya rata-rata $52 \%$ menjadi $72 \%$ pada siklus II dan $82 \%$ pada siklus III.

3. Pemahaman siswa terhadap materi pelajaran matematika mengalami peningkatan. Hal ini dapat ditunjukkan dengan rata-rata hasil ulangan harian siswa pada tiap akhir siklus setelah dilakukan implementasi model pendekatan Brain Gym (senam otak) mengalami peningkatan. Siklus I dengan KKM rata-rata 55,00 tuntas dengan rata-rata 63, siklus II dengan KKM 60,00 tuntas dengan rata-rata 71,4. dan siklus III dengan KKM 65,00 tuntas dengan rata-rata 80,6 .

4. Melalui pembelajaran model pendekatan Brain Gym (senam otak) pada proses pembelajaran dapat meningkatkan motivasi siswa untuk belajar, rasa percaya diri untuk mengerjakan tugas serta hasil belajar matematika siswa. 
5. Proses belajar mengajar yang menggunakan metode pembelajaran Brain Gym (senam otak) dapat membuat pembelajaran matematika lebih menyenangkan.

\section{DAFTAR PUSTAKA}

Arikunto, Suharsimi. Suhardjono. dan Supardi. (2009). Penelitian Tindakan Kelas. Jakarta: Bumi Aksara.

Asian Brain. "Motivasi”.http://www.anneahira.com/motivasi/index.htm,9/5/2010.

Dennison, Paul E. 2008. Brain Gym and me. Jakarta: Grasindo

Depdikbud. 1998. Kamus Besar Bahasa Indonesia. Jakarta: Balai Pustaka

Gunadi, Tri. 2009. Meningkatkan Kecerdasan Anak. Depok: Penebar Swadaya,.

Hudoyo, Herman. 1990.Strategi Mengajar Belajar Matematika. Malang: IKIP Malang,

Lie, Anita. 2002. Cooperative Learning. Jakarta: Gramedia, 2002.

Lubis, Muchlisin. 1999. Evaluasi Proses dan Hasil Pembelajaran. Jakarta: FMIFA UHAMKA, Manangkasi. (1987). Laporan Penelitian faktor-faktor yang Mempengaruhi (prestasi) Belajar Matematika Siswa SMTA. Ujung Pandang: FP MIPA. (Publication No.8).

Panen, Paulina. 2002. Belajar dan Pembelajaran I. Jakarta: Universitas Terbuka, 2002.

Suryabrata, Sumadi. 2008. Psikologi Pendidikan. Jakarta: Raja Grafindo Persada

Susilo. 2009. Penelitian Pendidikan. Jakarta: Poliyama Widya Pustaka, 2009.

Winataputra, Udin S. dan Tita Rosita. 1994. Belajar dan Pembelajaran. Jakarta: Universitas Terbuka.

Yurniwati. 2008. Belajar dan Bermain Matematika untuk SD/MI Kelas IV. Jakarta: Sinergi Pustaka Indonesia. 